\title{
On Problems and Development Strategies of the Construction of Student Apartment Cadres in Colleges and Universities: A Case Study of Sichuan University of Arts and Science
}

\author{
Yuan Yao \\ Department of Student Affairs, Sichuan University of Arts and Science, Dazhou, China \\ Email: 35523374@qq.com
}

How to cite this paper: Yao, Y. (2021) On Problems and Development Strategies of the Construction of Student Apartment Cadres in Colleges and Universities: A Case Study of Sichuan University of Arts and Science. Open Access Library Journal, 8: e7103. https://doi.org/10.4236/oalib.1107103

Received: December 22, 2020

Accepted: January 22, 2021

Published: January 25, 2021

Copyright $\odot 2021$ by author(s) and Open Access Library Inc.

This work is licensed under the Creative

Commons Attribution International

License (CC BY 4.0).

http://creativecommons.org/licenses/by/4.0/

\section{(c) (i) Open Access}

\begin{abstract}
The student apartment is an important place for students to learn, live and communicate with each other. It is also an important platform for the ideological and political education of college students, a window to show the spiritual civilization of the campus, and a "third class" for the cultivation of morality. It is of great significance to build and cultivate a group of student cadres with firm ideals and beliefs, deep patriotic feelings, noble moral character, strong desire for knowledge, spirit of self-reliance and high comprehensive quality in the college student apartment to realize the great rejuvenation of China.
\end{abstract}

\section{Subject Areas}

Education

Keywords

University, Student Apartment, Student Cadre, Education Platform

\section{Introduction}

The General Secretary Xi Jinping pointed out in his speech at the national education congress that what kind of people to cultivate is the first question of education. China is a socialist country under the leadership of the Communist Party of China. This has determined that our education must take the cultivation of socialist builders and successors as the fundamental task. This is the fundamental task of education and the goal of education modernization.

With the development of the importance of college student apartment as an 
education platform, it is an important part of college management work to strengthen and improve the education and administration of college student apartment. Therefore, it is essential to build a team of student cadres, and give full play to the advantages of students' subjective initiative and pioneer effect, so as to guide the majority of students to participate in the management actively, develop good living habits, form a strong learning atmosphere, and contribute to the overall development of apartment and university [1].

\section{The Establishment and Development of the Student Cadre Team}

The party committee of the university attaches great importance to the development and construction of student apartment. In 2016, it established the management and service center of student apartment, which is responsible for the construction and development of student apartment and student management services. In order to further strengthen the construction and development of the apartment, the center has set up a team of student cadres and the student apartment autonomous committee to assist the management service center to carry out various work of the student apartment.

Student apartment autonomous committee in nature belongs to the second level of autonomous organization, and was managed by the Department of Student Affairs and Youth League Committee. The student autonomy committee has a chairman and five departments: secretary department, discipline inspection department, cultural construction department, press center, and security department. Each department has a minister, 1 - 3 officers, and a supervisor in each building. The supervisor also holds a position in the committee. All positions are recruited in the form of work-study positions. Among them, the secretary department is responsible for writing and filing; the discipline inspection department is responsible for the safety inspection and internal hygiene inspection of student apartment; the responsibility of the cultural construction department is to plan and carry out the programs of arts and sports activities; the responsibility of the press center is to write and release news; the security department is responsible for assisting the administrator of the student apartment to guarantee the security of the apartment buildings and surrounding public areas.

In 2017, as the enrollment continued to expand, the number of students living in the apartment also increased sharply. According to the actual development of the university and the spirit of Measures of Sichuan Province for the Administration of College Student Apartment, the management service center of student apartment has formulated and implemented the grid hierarchical management mode to further strengthen the educational management of student apartment.

Student apartment autonomous committee was renamed the student apartment self-governing committee. The former five subordinate departments were combined into four departments: discipline inspection department, cultural and construction department, news center and rights and interests department. Each 
department has a chief and deputy minister and 3 - 5 officers. Each building has added one more supervisor, and each dormitory has a room leader. The chairman, chief and deputy ministers are appointed by special students, which has changed the previous form, and the department officers are still held by the supervisors of each building. The work content and recruit method remain unchanged.

\section{The Responsibilities of the Student Cadres}

\subsection{Responsibilities of the Chairman}

To formulate various rules and regulations; to be responsible for the formulation and arrangement of weekly, monthly and annual work plans; to be responsible for summarizing and sorting monthly and annual work summaries; to be responsible for coordinating the work of each department leader, supervisor, and room leaders within the committee; to be responsible for the arrangement and implement of regular work meetings and special meetings; to assist management staff in cultural construction and activities; to finish other tasks assigned by the center.

\subsection{Responsibilities of the Ministers}

To be responsible for the formulation and arrangement of weekly, monthly and annual work plans of the department; to be responsible for summarizing and sorting out monthly and annual work summaries of the department; to be responsible for the arrangement and personnel allocation of various work of the department; to be responsible for training and improving the working ability of department officers; to be responsible for other work assigned by the center.

\subsection{Responsibilities of Supervisors of Each Building and Floor}

The supervisors of each building and floor are the core strength of student cadres in each student apartment building. In addition to doing a good job as an officer of their department, they also need to do the following work in this building: to be responsible for assisting the apartment administrator in the daily management of the student apartment; to be familiar with the student information of the building and floor and the facilities and equipment in the building; to be responsible for regular dormitory safety and cleanness inspection; to be responsible for implementation of cultural activities; to be responsible for the collection and feedback of students' opinions; to be responsible for other work assigned by the center.

\section{The Problems Existing in the Construction and Development of Student Cadre Team in Student Apartment}

\subsection{Limited Recruitment Channels}

In the early stage of its establishment, the self-governing committee of the stu- 
dent apartment recruited student cadres by the way of campus work-study mutual selection, which is still used today, but the selection has the characteristics of time and group orientation. In terms of the process of team construction and management of the committee, there are some problems such as the lack of flexible recruitment time and limited applicants for student cadres in the recruitment based on the mutual selection job fair. For example, the mutual selection job fair, based on campus work-study positions for recruitment, offers jobs only for a small group of students, most of whom are from poor family, which means that the job fair has great limitations, and is essentially different from the traditional student cadre selection in teaching departments.

\subsection{Lack of Long-Term Cadres}

Due to the differences in their posts, the payment also differs somewhat. Therefore, based on the actual situation of the development of student apartment, the management service center has carried out internal improvement and regulation to the self-governing committee of student apartment for many times, but there are still some problems.

Firstly, due to the different wages of student cadres of different positions, it is inevitable that there is a certain psychological comparison between them, and they who fail to be elected in the annual election often have a sense of depression, so they choose to quit their jobs. For example, the salary of the supervisor is 10 yuan/hour, the department leader 300 yuan/month, and minister and positions above 400 yuan/month. It is actually a pay distinction according to the workload of the post, but often this will form a comparison between student cadres. At the same time, the election will not be absolutely fair. Therefore, psychological unbalance will be formed because a small number of student cadres think that they have worked hard on the post, and they are competent to be elected but fail to be promoted. Secondly, as the student cadres step to the senior grade, their academic pressure also increases accordingly, and some student cadres cannot seek a balance between study and work, thus choose to give up to serve as the student cadre actively [2]. Thirdly, some student cadres are with a curiosity to join the team, but have a weak sense of ability, creativity and subjective initiative. With the disappearance of excitement and the increase of daily work, they begin to show the signs of procrastination, buck-passing, or even leave without reason, etc., leaving a certain negative impact on the team members.

\subsection{Low Sense of Identity}

The traditional student cadre teams such as class, department student union, university student union are still the first choice for most students. Although the student cadre team of the apartment belongs to the university-level student autonomous organization, it is slightly marginalized in all the student cadre teams due to the narrow scope of power and responsibility and inconspicuous work 
position, which has not been well recognized and accepted by the majority of students.

\subsection{Low Degree of Coordination}

The degree of cooperation between the self-governing committee of the student apartment and the labor department of the student union and the teaching department is not high. It is mainly manifested in the aspects of large differences in working mechanism, low frequency of work contact and communication, and the vacuum space of working intersection. For instance, the inspection standards, time and intensity of three departments, the Department of Labor and Life of the university, the Department of Labor and Life of the Teaching units and Self-governing Committee of the Student Apartment, are not unified, and the definition of the types of forbidden electrical appliances is different, which leads to the final inspection results are difficult to be applied to the actual education and management of student apartment. What's more, the three departments carried out the inspection work in their own way, resulting in inspections of one room three times in a week, which affected students' study and life to a certain degree.

\subsection{Lack of Full-Time Staff}

The student apartment management service center is directly responsible for the management and guidance of the self-governing committee, but there are only two teachers actually do the work, which shows weakness in terms of teaching resources, and the strength and comprehensiveness of guidance are insufficient, so it is difficult to meet the actual needs of the development of student cadres.

\section{On the Construction and Development Strategies of Student Cadres in Student Apartment}

\subsection{To Change Team Feature and Strengthen Team Stability}

From the author's experience of guiding the student cadre team, it is a road worth exploring to abolish the existing form of recruitment of student cadres and transform the self-governing committee of the student apartment from a work-study team to a real student cadre team.

Firstly, it is important to change the orientation of the recruitment group, so that more students with interest, ideas and ability can take the initiative to apply; Secondly, we can recruit new students together with the student union and the association union, so as to timely supplement new force [3]. Thirdly, the thought of some student cadres should be fundamentally changed. They should realize that it is their responsibility to assist the administrators to do a good job in the apartment management service center by the ways in which apartment administrators holding student cadre meetings to strengthen training, enhancing the ability of teachers to guide students, carrying out team building activities, etc. They should also have a sense of mission, so as to stimulate their own initiative 
to actively participate in the management. Lastly, to achieve the unity of the team and avoid different payment and treatment that may have a negative impact on the construction and development of the team.

\subsection{To Cooperate with Teaching Departments to Jointly Promote Development}

The construction and management of student dormitory involves all the students in campus. Therefore, the construction and development of student apartment is not only the work of a single department, but the work of the whole university. There is a great connection among the cadre team of the university and the teaching departments and the autonomous management committee of the student apartment.

Firstly, all three teams serve students on campus. Secondly, their work rights and responsibilities are all carried out in the student apartment, and they share the same platform. The three teams can carry out regular work exchange and meeting to strengthen the communication on the work of the university, forming the integrity and linkage of the work. A part of the student cadres of the autonomous management committee of the student apartment share a position in the other two groups, serving as a bridge for exchanging ideas on the job.

\subsection{To Increase the Number of Faculty and Enhance Capacity}

Teachers are the thought leaders of the student, and they are the soul of the student team, thus they play an important role in the student cadres. The growth of student cadres needs a process and experiences, and teachers are the leaders in the process.

First of all, we should improve the relevant system and mechanism of instructors, assign corresponding instructors according to the number of students, recruit and select teachers from the whole university, and ensure the adequacy of teachers [4]. In addition, it is important to further improve the working mechanism, enable counselors in the teaching departments to participate in the apartment management, form a perfect work chain, and further supplement the shortage of teachers.

\subsection{To Perfect Incentive Measures to Stimulate Students' Internal Motivation}

The improved autonomous management committee of student residence should further enhance the incentive measures to ensure the vitality and motivation of the student cadre team. For example, it is necessary to set a certain number of seats on the selection of advanced individuals to promote team construction, strengthen the assessment of student cadres, standardize the selection files, quantify the work tasks [5], and select outstanding student cadres for reporting in the year-end summary meeting, motivating the majority of student cadres with advanced personal outstanding deeds. Moreover, to strengthen the management of active applicants and probationary party members among student 
cadres, timely give feedback to the student party branch through the daily work assessment, stimulate the endogenous motivation of student party members, and give full play to the advantages of leading and exemplary student party members.

\section{Conclusion}

The establishment of the autonomous management committee in Sichuan University of Arts and Science was later than most of the student societies, so the team construction and development need to be constantly improved. In brief, there are four ways to be considered. Firstly, it is necessary to set up posts scientifically and select truly excellent student cadres to develop and strengthen the power of the self-management association. Secondly, an effective linkage mechanism should be established to form a joint management team by administrative departments and teaching units. Thirdly, a strict selection system of excellent teachers for guiding students should be set up to improve the cultivation of student cadres. Lastly, an effective assessment and incentive mechanism should be formed to stimulate the internal motivation of the team. In this way, it is possible to explore a management system and mechanism that is consistent with the reality of university development, apartment management and students' self-education, management and service.

\section{Conflicts of Interest}

The author declares no conflicts of interest regarding the publication of this paper.

\section{References}

[1] Lin, F.J. (2011) Strengthening the Construction of Student Cadre Team in Student Apartment: A Case Study of Zhejiang University City College. Economic Perspective, No. 12, 103-104.

[2] Fang, Z.H. and Ding, Y.L. (2009) To Strengthen the Cultivation of Student Cadres in Apartments and Promote the Construction of Harmonious Apartments in Colleges and Universities. Education Management, No. 5, 156-157.

[3] Tong, L.H. (2010) How to Further Promote and Improve the Construction of College Apartment Student Cadre Team. Journal of Reading and Writing, No. 7, 83.

[4] Shan, Y. (2016) Research on the Construction of Student Cadres in Local Colleges and Universities: Based on the Investigation of Hunan Province. Hunan Agricultural University, Changsha.

[5] He, S.W. (2017) Innovative Research on the Education and Management of College Student Cadres. Journal of Harbin Vocational and Technical College, No. 1, 80-82. 